\title{
Evaluation of the effectiveness of the Chronological Dental Mineralization Table of Permanent Teeth among Brazilians in the city of Belo Horizonte
}

\author{
Avaliação da efetividade da Tabela Cronológica da Mineralização dos Dentes Permanentes entre \\ Brasileiros na cidade de Belo Horizonte \\ Evaluación de la efectividad de la Tabla Cronológica de Mineralización de Dientes Permanentes
} entre Brasileños en la ciudad de Belo Horizonte

Received: 12/08/2021 | Reviewed: 12/14/2021 | Accept: 12/22/2021| Published: 01/02/2022

\author{
Bárbara Taíny Barbosa Niquini \\ ORCID: https://orcid.org/ 0000-0002-8371-8645 \\ Pontifícia Universidade Católica de Minas Gerais, Brasil \\ E-mail: barbaraniquini@ hotmail.com \\ Aline de Freitas Fernandes \\ ORCID: https://orcid.org/0000-0003-0677-531X \\ Pontifícia Universidade Católica de Minas Gerais, Brasil \\ E-mail: draalinefernandes@hotmail.com \\ Fernanda Capurucho Horta Bouchardet \\ Pontifícia Universidade Católica de Minas Gerais, Brasil \\ E-mail: fernandacapurucho@gmail.com \\ Flávio Ricardo Manzi \\ ORCID: https://orcid.org/0000-0001-9467-5137 \\ Pontifícia Universidade Católica de Minas Gerais, Brasil \\ E-mail:dr.manzi77@gmail.com
}

\begin{abstract}
The knowledge of an individual age, especially children and young people, is important in civil and criminal cases, such as adoption and when is important determining criminal imputability. To estimate this age, when there are no suitable documents to prove it, body development factors are used, especially those that show the stages of mineralization of the teeth. To this estimation, numerous tables have been developed in the most diverse regions. The aim of this study was to analyze the accuracy of the Chronological Table of Mineralization of Permanent Teeth among Brazilians in a region different from that in which the method was developed, namely, Vale do Paraíba (SP - Brazil). For this purpose, 442 panoramic radiographs of individuals aged 5 years to 20 years and 4 months, taken in the central region of the city of Belo Horizonte (MG), were used. After applying the table, with the determination of the stages of each tooth present in the radiograph and an average between them, using the data developed by the authors, the total average percentage of correct answers was $63.5 \%$, showing a low number, especially in the age range of 14 to 17 years. When the estimate was analyzed for sexual dimorphism, no significant differences were found. Through this study, one can perceive a need for standardization and detailing in the methodology, besides its updating and complementation with data that encompass dental development in the different regions of the country.
\end{abstract}

Keywords: Forensic dentistry; Forensic anthropology; Radiography; Panoramic.

\section{Resumo}

Conhecer a idade de um indivíduo, em especial as crianças e os jovens, torna-se importante em casos civis e penais, a exemplo da adoção e da determinação da imputabilidade penal do mesmo. Para que seja feita a estimativa dessa idade, quando não existem documentos idôneos que a comprovem, utilizam-se fatores de desenvolvimento corporais, principalmente aqueles que demonstram os estágios de mineralização dos dentes. Para isso, inúmeras tabelas foram desenvolvidas nas mais diversas regiões. O objetivo deste estudo, foi analisar a acurácia da Tabela Cronológica da Mineralização dos Dentes Permanentes entre Brasileiros em região diferente daquela em que o método foi desenvolvido, nomeadamente o Vale do Paraíba (SP - Brasil). Para isso, utilizou-se 442 radiografias panorâmicas de indivíduos na faixa etária entre 5 anos e 30 anos e 4 meses, realizadas na região central da cidade de Belo Horizonte (MG). Aplicada a tabela, com a determinação dos estágios de cada dente presente na radiografia e uma média entre eles, utilizando os dados desenvolvidos pelos autores, a média percentual total de acertos foi de $63,5 \%$, demonstrando um baixo número, principalmente na faixa etária dos 14 aos 17 anos. Ao ser analisada a estimativa quanto ao dimorfismo sexual, não foram encontradas diferenças significantes. Através do estudo, pode-se perceber uma 
necessidade de uniformização e detalhamento na metodologia, além de sua atualização e complementação com dados que englobem o desenvolvimento dentário nas diferentes regiões do país.

Palavras-chave: Odontologia forense; Antropologia forense; Radiografia panorâmica.

\section{Resumen}

Conocer la edad de un individuo, especialmente los niños y los jóvenes, se vuelve importante en casos civiles y penales, como la adopción y la determinación de la responsabilidad penal. Para estimar esta edad, cuando no existen documentos acreditados que lo demuestren, se utilizan factores de desarrollo corporal, especialmente aquellos que demuestran las etapas de mineralización de los dientes. Para ello, se desarrollaron numerosas tablas en las más diversas regiones. El objetivo de este estudio fue analizar la exactitud de la Tabla Cronológica de Mineralización de Dientes Permanentes entre brasileños en una región distinta a aquella en la que se desarrolló el método, a saber, Vale do Paraíba (SP - Brasil). Para ello, se utilizaron 442 radiografías panorámicas de individuos con edades comprendidas entre los 5 años y los 30 años y 4 meses, tomadas en la región central de la ciudad de Belo Horizonte (MG). Luego de aplicar la tabla, con la determinación de los estadios de cada diente presente en la radiografía y un promedio entre ellos, utilizando los datos desarrollados por los autores, el promedio porcentual total de respuestas correctas fue $63.5 \%$, demostrando un número bajo, principalmente en el grupo de edad de 14 a 17 años. Al analizar la estimación del dimorfismo sexual, no se encontraron diferencias significativas. A través del estudio se percibe la necesidad de estandarizar y detallar la metodología, además de su actualización y complementación con datos que engloben el desarrollo odontológico en diferentes regiones del país.

Palabras clave: Odontología forense; Antropología humana; Radiografía panorámica.

\section{Introduction}

The knowledge of the age of an individual is an important part of human identification (Maia et al., 2010). In Forensic Dentistry, age estimation in living individuals has become increasingly important (Azevedo et al.,2015; Cameriere et al., 2006), both civilly and criminally. Performing a study of this nature is always requested when the real age is unknown, either because the individual is not capable or does not volunteer to provide a document that attests it, or when the document provided has its suitability under suspicion (Azevedo et al.,2015; Thevissen et al., 2010). The importance of this knowledge is due to the need to provide equal rights to individuals who do or do not have the ability to attest to this data (Olze et al., 2004).

In Brazil, this estimate in young living individuals is largely required when one wants to know if he or she can be held criminally responsible as an adult, the age limit in the country being 18 years (Franco et al., 2013; Panchbhai, 2011)], and in sexual crimes with victims under 14 years of age, another age limit widely investigated (Franco et al., 2013). Other countries also consider knowledge of these two ages, 14 and 18, as important in criminal cases as Brazil does (Olze et al., 2004). In Russia, for example, many immigrants who are within this age range, between 14 and 18, arrive in the country illegally unaccompanied by adults, these young people may engage in criminal activities, illegal work and be subjected to sexual violence, negative consequences of this process (Scendoni et al., 2020).

The study of teeth through their mineralization, when analyzing the stages of body development, is only one of the indicators that can be used to estimate the age of an individual (Gioster-Ramos et al., 2021). The study stages of tooth irruption, secondary sexual characters, the relationship between size and weight of the individual and his bone development can be done too.

This body development can be affected by factors such as climate, environment, nutrition, genetics and other (Kurita, Menezes, Casanova, \& Haiter-Neto, 2007). When analyzed the age estimation in children, the study of dental development presents itself as a better alternative than studies that use bone maturation, which is more affected in its development by environmental (Cameriere et al. 2006; Panchbhai, 2011; Tomás et al., 2014) and hormonal (Tomás et al., 2014), nutritional (Mazzilli et al., 2018), pathological (Panchbhai, 2011) and endocrine (Eid et al., 2002) factors. Tooth mineralization is more controlled by genetic factors and thus has less variation in this process (Cameriere et al. 2006; Panchbhai, 2011).

The teeth genesis and their apical closure being less variable than these other events of body development (Maia et al.,2010) are considered the basis for more definitive and consequently more useful methods to estimate chronological age (Eid 
et al., 2002) developed by different authors to estimate the age of children and adolescents (Maia et al.,2010). In this context, dental radiology provides a large amount of information about teeth, being an important area when it comes to age estimation in humans (Panchbhai, 2011). This is because through radiographic analysis all the stages of tooth mineralization can be viewed. Thus, many methods use oral radiographs (Eid et al., 2002), since most of them basically require that the degree of mineralization of teeth be defined and that this degree be related to stages previously determined in tables (Panchbhai, 2011; Eid et al., 2002; Cameriere et al. 2006; Cameriere et al., 2008; Mazzilli et al., 2018), as is the case of the Chronological Table of Mineralization of Permanent Teeth among Brazilians (Nicodemo et al., 1974).

To perform this study in a child or adolescent, dental mineralization processes are widely used and studied (Maber et al., 2006). One of the methods used for the estimation by teeth, the already mentioned table developed by Nicodemo, Moraes and Médici Filho in 1974, uses all stages of mineralization of all permanent teeth and has a specific table to our population (Franco et al., 2013). The accuracy of this and other methods that use tooth development has been investigated in previous works (Cameriere et al. 2008; Maber et al., 2006).

The objective of this study was so to analyze the applicability of this method exposed to the scientific community by the article Chronological table of mineralization of permanent teeth among Brazilians published in 1974, to the population of the city of Belo Horizonte now a days.

\section{Methodology}

This research was approved by the Ethics Committee of the Pontifical Catholic University of Minas Gerais (Opinion: 1.854.431). It was used 442 panoramic radiographs of individuals aged between 5 and 20 years and 4 months, of both genders, numbers shown in Table 1, performed in a dental radiology clinic, located in the central region of the city of Belo Horizonte MG, in the period from August 13, 2014 to December 15, 2016, which met the research age criteria and had a satisfactory level of quality for evaluation.

The table and method developed by Nicodemo, Moraes and Médici Filho and applied in Forensic Medicine Institutes in Brazil was used. Each permanent tooth present in the radiographs was related to the stage of formation demonstrated by the authors and its time interval in the table developed by them.

The digital images were interpreted directly in the KDIS software, and the use of all available resources was allowed, which were duly explained to the observers. Computers with GeForce 9500 GT graphics card (Nvidia Corporation) and LG Flatron E2241 LED monitor (LG Electronics) were used, with a 1920x1080 pixels resolution and the brightness and contrast levels of the monitor fixed at their pre-established settings. The radiographs were evaluated randomly. To avoid compromising due to visual fatigue, the analysis was limited to 30 images per day.

The first step was to compare the mineralization stages of the permanent teeth present in the radiographs and the stages determined by Nicodemo, Moraes and Médici Filho: The mineralization stages were established considering the way that they were presented in the article that introduces the method, as follows Stage 1 - First evidence of crown mineralization; Stage 2 - 1/3 of crown formed; Stage 3 - 2/3 of crown formed; Stage 4 - Crown complete; Stage 5 - First evidence of root formation; Stage 6 - 1/3 of root formed; Stage 7 - 2/3 of root formed; Stage 8 - Apical termination.

The development of the estimates by means of the table was performed by evaluating the permanent teeth. All the teeth present were used, including the third molars. When only these teeth were in some stage of mineralization and the other teeth presented apical closure, only the third molars were used. Each tooth was then classified according to its stage of mineralization established by Nicodemo, Moraes and Médici Filho. After this determination, the stages of each tooth were related to the estimated maximum and minimum time in months present in the table, referring to the average time in which this 
stage occurs; All minimum and maximum values were added, after exclusion of very discrepant values in individuals in which few teeth remained in some stage of mineralization; The result was acquired in months and then transformed into years, by dividing the result by 12 ;

For ages between 5 years and 20 years and 4 months, estimates in which the chronological age of the individual fit within the time period between minimum and maximum age found when applying the method were classified as "true" and as "false" those which the age did not fit.

For Inter-examiner analysis, the total number of radiographs was randomly evaluated by two independent, properly trained and calibrated dental surgeons with experience in interpreting radiographic images. To avoid compromising due to visual fatigue, the analysis was limited to 30 images per day.

To evaluate the intra-examiner agreement the images were analyzed in two different moments by one of the dental surgeons. In the second moment only a sample of $33 \%$ of the total (152 observations) of the images was used.

All analyses were performed using R statistical analysis software (R CORE TEAM, 2020). The agreement between the evaluations was evaluated according to Cohen's Kappa statistic. Additionally, the Prevalence-adjusted and bias- adjusted Kappa (PABAK) statistic, the prevalence index (PI) and the bias index (BI) were calculated.

The proportion of correct answers in the given age groups and in the female and male sexes was compared by the Ztest.

\section{Results and Discussion}

The radiographs used were analyzed according to the sex of the subjects and the age groups of 5 to 13 years, 14 to 17 years, and 18 to 20 years and 4 months (Table 1 ).

Table 1: Sample of panoramic radiographs used, regarding sex and age.

\begin{tabular}{ccccc}
\hline Age Group & $\begin{array}{c}\text { Gender } \\
\text { Female }\end{array}$ & Gender Male & Total \\
\hline $\begin{array}{c}5 \text { to } 13 \text { years } \\
\text { old }\end{array}$ & 138 & 145 & 283 \\
14 to 17 & 51 & 57 & 108 \\
years old & 32 & 19 & 51 \\
18 to 20 & & & \\
years old & & & 442 \\
\hline and 4 months & & 221 & 221 & \\
\hline
\end{tabular}

Source: Authors.

Table 2 presents the agreement value between the evaluations performed by Evaluator 1 and Evaluator 2, and Table 3 presents the agreement value between the evaluations performed by Evaluator 1 at two different times measured by Cohen's Kappa and PABAK statistics, as well the prevalence index (PI) and the bias index (BI). 
Research, Society and Development, v. 11, n. 1, e4711124531, 2022

(CC BY 4.0) | ISSN 2525-3409 | DOI: http://dx.doi.org/10.33448/rsd-v11i1.24531

Table 2: Interobserver evaluation result.

\begin{tabular}{|c|c|c|c|}
\hline \multirow{2}{*}{ Evaluator 1} & \multicolumn{2}{|c|}{ Evaluator 2} & \multirow{2}{*}{ Total line } \\
\hline & True & False & \\
\hline True & 212 & 38 & 250 \\
\hline False & 94 & 98 & 192 \\
\hline \multirow[t]{2}{*}{ Column total } & 306 & 136 & 442 \\
\hline & Value & $95 \% \mathrm{CI}$ & p-value \\
\hline OP (\%) & 70,13 & & \\
\hline PE (\%) & 52,52 & & \\
\hline Kappa & $0,37 \pm 0,045$ & $0,28-0,46$ & $<0,001$ \\
\hline PABAK & 0,41 & $0,32-0,49$ & - \\
\hline PI & $0,25 \pm 0,03$ & $0,19-0,32$ & \\
\hline BI & $0,12 \pm 0,03$ & $0,18-0,06$ & \\
\hline
\end{tabular}

PO. Observed proportion of agreement; PE: Expected proportion of agreement; PABAK = Prevalence-Adjusted and BiasAdjusted Kappa; PI: Prevalence index; BI: Bias index; Source: Authors.

When analyzing the results of the observers, the proportion of observed agreement (PO) was $70.13 \%$ while the proportion of expected agreement by chance was $52.52 \%$. The chance-corrected agreement expressed by the Kappa value was $0.41(41 \%)$ indicating that there was poor agreement between the raters.

In the evaluation of the results from the same observer, the proportion of observed agreement (PO) was 70.54\%. The agreement index obtained by the Kappa coefficient 0.40 also indicated a weak agreement between the evaluations. The low value observed for the Kappa index can be justified by the fact that a higher proportion of "True" than "False" was observed at different times by the rater, indicating low repeatability of the evaluations. The proportion of agreement expected to be obtained by chance (EP) was $50.45 \%$. This high proportion makes the agreement obtained between the evaluations low. 
Table 3: Intraobserver evaluation result.

\begin{tabular}{cccc}
\hline \multirow{2}{*}{ Observation 1 } & \multicolumn{2}{c}{ Observ ation 2 } & Total line \\
\cline { 2 - 3 } & True & False & 76 \\
\hline True & 61 & 15 & 70 \\
False & 28 & 57 & p-value \\
\hline Column total & Value & $\mathbf{9 5 \%}$ CI & \\
\hline OP (\%) & 70,54 & & $<0,001$ \\
PE (\%) & 50,45 & $0,24-0,56$ & \\
Kappa & $0,40 \pm 0,081$ & $0,24-0,55$ & \\
PABAK & 0,41 & $0,02-0,24$ & \\
PI & $0,13 \pm 0,05$ & $0,20-0,024$ & \\
BI & $0,089 \pm 0,05$ &
\end{tabular}

PO: Observed proportion of agreement; PE: Expected proportion of agreement; PABAK = Prevalence-Adjusted and Bias-Adjusted Kappa; PI: Prevalence index; BI: Bias index. Source: Authors.

Tables 4 and 5 show the percentage of correct answers of the observers according to gender and age groups determined for this study. The total average percentage of correct answers was $63.5 \%$. There was no percentage difference between the estimates of individuals of both sexes. As for the age group, the average percentage was $63.26 \%$ for subjects between 5 and 13 years old, $54.98 \%$ among those between 14 and 17 years old, and $83.24 \%$ in the age group 18 to 20 years old.

Table 4: Percentage of correct answers according to Age Groups.

\begin{tabular}{cccc}
\hline Age Group & Observer 1 & Observer 2 & Average \\
\hline 5 a 13 & 56,45 & 70,07 & 63,26 \\
14 a 17 & 47,93 & 62,04 & 54,98 \\
18 a 20 & 85,71 & 80,77 & 83,24 \\
\hline
\end{tabular}

Source: Authors.

Table 5: Percentage of hits according to Gender.

\begin{tabular}{cccc}
\hline Sex & Observer 1 & Observer 2 & Average \\
\hline Female & 58,70 & 69,51 & 64,10 \\
Male & 56,70 & 69,23 & 62,96 \\
Total & 57,70 & 69,37 & 63,53 \\
\hline
\end{tabular}

Source: Authors. 
All evaluations by both observers were considered in the analysis of the age range variable. The ages of each of the individuals evaluated were grouped into one of the following age groups: 5 to 13 years; 14 to 17 years; and 18 to 20 years. The proportion of hits (True) among each age group is shown in Table 6. The proportion of hits was compared by Z-test ( $\mathrm{p}<0.05$ ). There were significant differences between the proportion of correctness across the age groups evaluated ( $\mathrm{p}<0.001)$. The comparison of the proportion of correct answers between pairs of age groups showed that the proportion of correct answers was higher in individuals between 18 and 20 years old.

Table 6: Comparison of the proportion of correctness between pairs of age groups.

\begin{tabular}{ccc}
\hline Age Group & TRUE & FALSE \\
\hline & & \\
\hline a 13 & 0,6254 a & 0,3745 \\
14 a 17 & 0,5462 a & 0,4537 \\
18 a 20 & $0,8235 \mathrm{~b}$ & 0,1764 \\
\hline
\end{tabular}

${ }^{1}$ Different letters indicate statistical difference between the proportion of correct answers obtained in each age group $(\mathrm{p}<0.05)$. Source: Authors.

Similar analysis to the age range was used to study the results regarding the gender of the individuals evaluated.

As can be seen in Table 7, their sex was not a determinant of the True (actual age falling within the estimated age range found) proportion among the sex groups $(\mathrm{p}<0.05)$.

Table 7: Comparison of the proportion of correct answers between genders.

\begin{tabular}{ccc|c}
\hline Sex & True & False & Total line \\
\hline Male & 0,629 & 0,371 & 442 \\
Female & 0,629 & 0,371 & 442 \\
\hline Total Column & 1,257 & 0,742 & 884 \\
\hline
\end{tabular}

Source: Authors.

Estimation studies are largely focused on children and adolescents. According to many researchers, errors in age estimation increase when the child is older than 10 years of age (Bolaños et al., 2013).

During childhood there are several permanent teeth developing simultaneously, so age through teeth can be found more accurately (Liversidge et al., 2003; Prieto et al., 2005). After the age of 14, this estimation is considered even more difficult since a smaller number of teeth are at some stage of development and often only the third molars can be used, which are considered the teeth with the lowest consistency of all, when taking into account time of mineralization and age of eruption (Bolaños et al.,2013; Prieto et al., 2005).

The division into the age groups of 5 to 13,14 to 17 , and 18 to 20 years and 4 months was done to make it possible to analyze the effectiveness of the table at the age when teeth are most developed, up to the age of 14. Moreover, determining whether an individual is older or younger than 14 becomes important in the Brazilian penal qualification, as well as that of 
many other countries. Following this reasoning, it is equally important to determine whether an individual is younger or older than 18 when he or she reaches the age of criminal responsibility (Olze et al., 2004).

The proportion of correct answers in this study was higher among individuals younger than 14 years (5 to 13 years and 11 months) than among those in the age range 14 to 17 years. Due to the smaller number of developing teeth, the method presents difficulties to observers, and consequently to experts, to achieve a successful estimation. When using the table, some teeth show very low ages of apical termination, having reached stage 8 many years ago by the studied individual. This decreases the mean age, which may lead to an estimate classified as "False" in this study and different from the real age in everyday practices.

On the other hand, the observers obtained better results, when using the Nicodemo and co-workers table, in the age group that comprises the ages between 18 and 20 years and 4 months. This can be explained by the use of a smaller number of teeth in the study of this age group. In this group, the mean is not so influenced by the presence of teeth that have already matured for a longer period of time.

When analyzing the proportion of correct answers regarding sexual dimorphism, the sex of the individuals was not a determining factor to modify the levels found, since there was no significant difference between those found in male and female individuals. In 1992, Nicodemo and co-workers developed a chronological table of the mineralization of permanent teeth under the aspect of gender differences (Nicodemo et al., 1992). We noticed through the present analysis that there is no need to develop different tables based on the sex of children and young adults for age estimation.

Moreover, the reproducibility of methods that seek to assess the stages of mineralization of teeth, especially when involving crown and root can be influenced by some factors, which makes them more difficult and subjective. This classification makes them less accurate because it must be done by listing a stage of development, but without knowing for sure what size this tooth will reach (Maber et al., 2006). This factor exposes the subjectivity of the method, suggesting that it may be one of the explanations for the disagreement between the evaluations developed in this study. In addition, articles such as the one published by Nicodemo and colleagues, do not provide important details for the development of the method, which means that many decisions made during the estimation may differ between the evaluators and even between the evaluations of the same dental surgeon.

Although the methods that use the comparison of the stages of mineralization and pre-existing tables are used precisely for their simplicity and the small number of resources needed for their confection, they present an inevitable variation of results that will depend on the evaluator who will perform it and this is considered a problem. Even if, in some research, there is an adjustment and control between the examiners, this does not occur in daily practice (Mazzilli et al., 2018).

Finally, it is important that methods that measure development and growth of an individual take into account hereditary, functional, nutritional, sexual, metabolic and environmental factors and have standards that serve specific populations (Maia et al.,2010), since ethnic origin can influence dental mineralization (Gioster-Ramos et al., 2021) and consequently the studies and tables regarding estimation (Olze et al., 2004). This origin must then be considered when making this estimate and expansion of ethnic data for this purpose is necessary (Scendoni et al., 2020).

It happens that dental maturation, even if in smaller numbers than other indicators, can also be influenced by factors such as socioeconomic status, degree of urbanization, climate, nutrition. There is extensive documentation which states that different populations also have differences in markers for age estimation by teeth (Kurita et al., 2007).

The study by Nicodemo, Moraes and Médici Filho (1974), for example, for the development of the Chronological Table of Mineralization of Permanent Teeth among Brazilians used a sample of 478 radiographs of Brazilian leucodermic individuals aged between 0 and 25 years, reaching the conclusion that the tables available in the literature were not applicable 
to the Brazilian population. During this study, they used images from a homogeneous population living in the same area of the Brazilian State of São Paulo (Nicodemo et al.,1974; Veras et al., 2021).

The applicability of methods developed in individuals of ethnic groups divergent from those in which they are applied has been the subject of much discussion (Prieto et al., 2005). This questioning occurs precisely because of the difference in results found when using specific patterns of one ethnic group in another, being motivated by the different development found in different ethnic groups (Schmeling, Olze, Reisinger \& Geserick, 2004).

In order for the result achieved in age estimation research not to be called into question during legal proceedings, it is necessary that the sample used to develop the method apllied to estimate age be of individuals of the same ethnic origin of the individual studied (Thevissen et al., 2010).

When talking about the Brazilian population, it is understood that it is formed by people belonging to different ethnic groups, and is quite heterogeneous (Eid ei al., 2002). This heterogeneity, compared to a specific group of leucodermic individuals living in a certain area, conditions in which the table analyzed in this study was developed, may be an important factor for understanding the low percentage of correctness of the total estimates made.

Some previous studies have already shown that when applying methods in certain populations, being developed for others with differences besides geography, in socioeconomic, nutritional, and ethnic conditions, different results are found. This leads us to believe that it is necessary to develop appropriate methods for each population (Gioster-Ramos et al., 2021; Tomás et al., 2014). Knowing that the accuracy that is obtained when using specific methods and numbers for specific populations is high (Azevedo et al.,2015).

Considering the extension of Brazil, with so many regional differences, it would be of extreme value to establish parameters for each of its regions (Kurita et al., 2007). The table, currently used in the national territory, does not take into consideration data from individuals other than those analyzed during the study.

\section{Conclusion}

Techniques for estimating the age of an individual that take dental mineralization into consideration are of great importance in maintaining the rights and duties of children and adolescents.

This study perceived the effectiveness of the Chronological Table of Mineralization of Permanent Teeth among Brazilians when used to determine criminal responsibility, since it had satisfactory results in the age range of 18 to 20 years and 4 months. And the lack of need for the development of tables that take into consideration sexual dimorphism.

However, it can be seen that a deeper study of the methodology and its application is necessary, as well as its updating and complementation with data that encompass the dental development of the different regions of the country. It is recommended to study the applicability of the table in other regions of the country.

\section{References}

Azevedo, A. C. S., Alves, N. Z., Michel-Crosato, E., Rocha, M., Cameriere, R., Biazevic, M. G. H. (2015). Dental age estimation in a Brazilian adult population using Cameriere's method. Brazilian Oral Reserach, 29(1), 1-9. https://doi.org/10.1590/1807-3107BOR-2015.vol29.0016.

Bolaños, M. V., Moussa, H., Manrique, M. C., Bolaños, M. J. (2013). Radiographic evaluation of third molar development in Spanish children and Young people. Forensic Science International, 133, 212-219. https://doi: 10.1016/s0379-0738(03)00037-9.

Cameriere, R., Ferrante, L., Cingolani, M. (2006). Age estimation in children by measurement of open ápices teeth. International Journal of Legal Medicine, 120, 49-52. https://doi: 10.1007/s00414-005-0047-9.

Cameriere, R., Ferrante, L., Liversidge, H. M., Prieto, J. L., Brkic, H. (2008). Accuracy of age estimation in children using radiograph of developing teeth. Forensic Science International, 176,173-178. https://doi.org/10.1016/j.forsciint.2007.09.001. 
Eid, R. M. R., Simi, R., Friggi, M. N. P., Fisberg, M. (2002). Assessment of dental maturity of brazilian children aged 6 to 14 years using Demirjian's method. International Journal of Paediatric Dentistry, 12, 423-428. https://doi.org/10.1046/j.1365-263X.2002.00403.x.

Franco, A., Thevissen, P., Fieuws, S., Souza, P. H. C., Willems, G. (2013). Applicability of Willems model for dental age estimations in Brazilian children. Journal of Forensic Sciences,231, 1-3. https://doi: 10.1016/j.forsciint.2013.05.030.

Gioster-Ramos, M. L., Silva, E. C. A., Nascimento, C. R., Fernandes, C. M. S., Serra, M. C. (2021). Técnicas de identificação humana em Odontologia Legal. Research, Society and Development, 10, 3. http://dx.doi.org/10.33448/rsd-v10i3.13200.

Kurita, L. M., Menezes, A. V., Casanova, M. S., Haiter-Neto, F. (2007). Dental maturity as an indicator of chronological age: radiographic assessment of dental age in a brazilian population. Journal of Applied Oral Science, 15(2), 99-104. https://doi: 10.1590/s1678-77572007000200005

Liversidge, H. M., Lyons, F., Hector, M. P. (2003). The accuracy of three methods of age estimation using radiographic measurements of developing teeth. Forensic Science International, 131, 22-29. https://doi: 10.1016/s0379-0738(02)00373-0.

Maber, M., Liversidge, H. M., Hector, M. P. (2006). Accuracy of age estimation of radiographic methods using developing teeth. Forensic Science International, 159, 68-73. https://doi: 10.1016/j.forsciint.2006.02.019.

Maia, M. C. G, Martins, M. G. A., Germano, F. A., Brandão Neto, J., Silva, C. A. B. (2010). Demirjian's system for estimating the dental age of northeastern Brazilian children. Forensic Science International, 200, 1-3. https:// doi: 10.1016/j.forsciint.2010.03.030.

Mazzilli, L. E. N., Melani, R. F. H., Lascala, C. A., Palacio, L. A. V., Cameriere, R. (2018). Age estimation: Cameriere's open apices methodology accuracy on a southeast Brazilian sample. Journal of Forensic and Legal Medicine, 58, 164-168. https://doi: 10.1016/j.jflm.2018.06.006.

Nicodemo, R. A., Moraes, L. C., Médici Filho, E. (1974). Tabela cronológica da mineralização dos dentes permanentes entre brasileiros. Revista da Faculdade de Odontologia de São José dos Campos, 3(1), 55-6.

Nicodemo, R. A., Moraes, L. C., Médici Filho, E. (1992). Tabela cronológica da mineralização dos dentes permanentes sob o aspecto da diferença entre os sexos. Ortodontia, 25 (1), 18-35. https://pesquisa.bvsalud.org/portal/resource/pt/biblio-853035.

Olze, A., Schmeling, A., Taniguchi, M., Maeda, H., Niekerk, P., Wernecke, K., Geserick, G. (2004). Forensic age estimation in living subjects: the ethnic fator in winsdom tooth mineralization. International Journal of Legal Medicine, 118, 170-173. https://doi.org/10.1007/s00414-004-0434-7.

Panchbhai, A. S. (2011). Dental radiographic indicators, a key to age estimation. Dentomaxillofacial Radiology, 40, 199-212. https://doi.org/10.1259/dmfr/19478385.

Prieto, J. L., Barbería, E., Ortega, R., Magaña, C. (2005). Evaluation of chronological age based on third molar development in the Spanish population. Intenational Journal of Legal Medicine, 119 (6), 349-354. https://doi.org/10.1007/s00414-005-0530-3.

Scendoni, R., Galina, Z., Vanin, S., Pigolkin, Y., Cameriere, R. (2020). Forensic Validity of the Third Molar Maturity Index (I3M) for Age Estimation in a Russian Population. BioMed Research International, 1, 1-6. https://doi.org/10.1155/2020/6670590.

Schmeling, A., Olze, A., Reisinger, W., Geserick, G. (2004). Forensic age diagnostics of living people undergoing criminal proceedings. Forensic Science International, 144, 243-245. https://doi: 10.1016/j.forsciint.2004.04.059.

Thevissen, P. W., Algerban, A., Asaumi, J., Kahveci, F., Kaur, J., Kim, Y. K., G Willems, G. (2010). Human dental age estimation using third molar developmental stages: Accuracy of age predictions not using country specific information. Forensic Science International, 201, 106-111. https://doi: 10.1016/j.forsciint.2010.04.040

Tomás, L. F., Mónico, L. S. M., Tomás, I., Varela-Patiño, P., Martin-Biedma, B. (2014). The accuracy of estimating chronological age from Dermijian and Nolla methods in a Portuguese and Spanish sample. BMC Oral Health, 160. https://doi.org/10.1186/1472-6831-14-160.

Veras, N. P., Abreu-Pereira, C. A., Kitagawa, P. L. V., Costa, M. A., Lima, L. N. C., Costa, J. F., Casanovas, R. C. (2021). Avaliação de um método de estimativa de idade pela mineralização dentária dos terceiros molares. Research, Society and Development, 10, 7. http://dx.doi.org/10.33448/rsd-v10i7.16524. 